\title{
Anti-imperialism: The Leninist Legacy and the Fate of World Revolution
}

\author{
Jeremy Friedman and Peter Rutland
}

Political scientists moved on from studying the 1917 revolution some time ago. The collapse of communism meant that there was no longer a rival system to study, and hence less interest in understanding its origins in 1917. These days few political scientists study revolutions, 1917 or any other. ${ }^{1}$ Instead, they are focused on the role different political institutions and social movements play in achieving generally-agreed goals of peace, democracy, and prosperity. For example, the Arab Spring is seen more as a social movement than a revolution (or a failed revolution).

The 1917 revolutions created institutions that "failed" the test of historya “workers' state," a ruling Communist Party, central planning-and the corresponding ideology of world revolution and the destruction of capitalism. Political scientists are more interested in studying the revolutions which created the institutions of liberalism and nationalism that dominate the contemporary world, at least as seen from Washington: the French Revolution, the American Revolution (Hamilton!), and even England's Glorious Revolution of $1688 .^{2}$

But political scientists should be interested in 1917. It represents a unique case of total systemic breakdown, with sobering lessons for the stability of political and economic systems through to the present day.

\section{7 as a Black Swan Event}

We live in a world of increasing complexity and volatility. The revolution in transport and communications that began in the 1950s-60s radically accelerated the share of trade in the world economy, which was followed by the deeper integration of financial markets. With the information revolution that coincided with the collapse of communism (the first web site was launched

Thanks to Philip Pomper, Yoram Gorlizki, Alexander Semyonov, and Vladimir Kontorovich for comments on an earlier version.

1. For an overview, see the book by sociologist James DeFronzo, Revolutions and Revolutionary Movements, $5^{\text {th }}$ ed. (Boulder, 2015).

2. As for example in Douglass North, John Wallis and Barry Weingast, Violence and Social Orders: A Conceptual Framework for Interpreting Recorded Human History (Cambridge, UK, 2009). 
one week after the fall of the Berlin Wall), the pace of technological change has continued to accelerate, and with it growing uncertainty. ${ }^{3}$

The financial crash of 1998 began with a fall in export earnings in Indonesia and triggered a wave of financial panic that nearly brought down the US banking system. Russia defaulted on its debts and the old era of unrestrained oligarchic capitalism came to an end, thanks to a resurgent state headed by Vladimir Putin.

In the wake of the 1998 crisis, mathematician Nassim Taleb coined the phrase "Black Swan" to describe events that have a very low probability of occurrence but a very high impact when they do take place. Taleb argued that the number of Black Swan events would increase, since "globalization creates interlocking fragility, while reducing volatility and giving the appearance of stability." 4 Sure enough, the continued liberalization of international finance in the 2000s culminated in the 2008 crash, a cataclysm which all the economists and financial authorities not only failed to see coming, but whose models (such as the efficient markets hypothesis) insisted could not happen.

Similarly, on the political front we have seen a series of unpredicted and unpredictable events in recent decades: the collapse of the Soviet Union, the embrace of capitalism by the Chinese Communist Party, the rise to power of Vladimir Putin, the September $11^{\text {th }}$ attacks, the Arab Spring, the rise of ISIS, the Brexit referendum, the Trump election. It wasn't just that political scientists failed to predict these events-their very occurrence seemed incompatible with the prevailing theories that were being used to analyze the world. Even after they occurred, we had a hard time coming up with a convincing narrative to explain them. ${ }^{5}$

Political scientists have generally shied away from trying to embrace Taleb's thinking. ${ }^{6}$ Outside academia, there is an entire industry of political risk analysis, attaching probabilities to future scenarios and trying to advise governments and corporations how to adapt to a range of developments. ${ }^{7}$ But risk is not uncertainty: according to the classic definition by Frank Knight, risk can be measured and insured against, but uncertainty cannot. ${ }^{8}$ Academic political scientists, however, have not seriously engaged with the study of why political systems suffer catastrophic failure. In 1984, sociologist Charles Perrow laid out a useful model for explaining catastrophic accidents such as

3. Anthony Giddens, Runaway World: How Globalization is Reshaping Our Lives (London, 2002); Ulrich Beck, Risk Society: Towards a New Modernity (London, 2010). 2007).

4. Nassim Taleb, The Black Swan: The Impact of the Highly Improbable (New York,

5. One of the Russian biographies of Donald Trump refers to him as a "Black Swan.” Kirill Benediktov, Chernyi lebed': politicheskaia biografia Donalda Trampa (Moscow, 2016).

6. One exception is the special issue of Critical Review 21 no. 4 (2010). See the introduction by Mark Blyth, "Coping with the Black Swan: The Unsettling World of Nassim Taleb," Critical Review 21, no. 4 (December 2009): 447-65.

7. Ian Bremmer and Preston Keat, The Fat Tail. The Power of Political Knowledge for Strategic Investing (Oxford, UK. 2009). "Fat tail” is a term used by Nassim Taleb.

8. Frank H. Knight, Risk, Uncertainty and Profit (Boston, 1921). 
Three Mile Island. ${ }^{9}$ Like Taleb, Perrow stresses organizational complexity and "tight coupling" between disparate systems that may interact in unpredictable ways. One useful contribution by Nassim Taleb and Gregory Treverton analyzed the factors behind state failure, arguing that "although one cannot predict what events will befall a country, one can predict how events will affect a country." 10

This sort of approach is useful in trying to explain the collapse of the Soviet Union in 1991-something that has attracted surprisingly little attention from social scientists. ${ }^{11}$ It exemplifies the interaction of overlapping complex systems. Mikhail Gorbachev's struggle to reform the Soviet economy and ruling party triggered an opening for groups in the Baltic and Caucasus republics to pursue their nationalist agendas. These domestic systems in turn were closely connected to the politics of Soviet imperialism from Afghanistan to Poland, and with Ronald Reagan's post-Iran strategic assertiveness. Gorbachev knew that some sort of dignified withdrawal from Afghanistan would only be possible with help from the Americans-that, plus fears of Star Wars technologies, led him to pursue arms control negotiations with the United States, and to borrow heavily from the west to fund his ill-fated economic modernization program.

No single model could incorporate all these elements and attach probabilities to their likely path of development. Just as the Soviet collapse defies a deterministic social-scientific explanation, so too does the system's chaotic birth in 1917.

\section{The View from the Café Odeon}

If we are now living in the second wave of globalization in the modern era, then the first wave came in the period 1870-1914. New technologies (the train, the steam ship, electricity, the telegraph, industrial chemistry, and so on) facilitated massive industrial growth and a surge in international trade, which reached $9 \%$ of global GDP by 1914, a level not reached again until the 1970s (since when it has doubled, to $18 \%$ of GDP). ${ }^{12}$ These and related new technologies (such as lithographic and off-set printing, photography, cinema and radio) also brought a wave of disruptive political developments-the enfranchisement of the majority of male citizens, and the rise of mass movements 1984).

9. Charles Perrow, Normal Accidents: Living with High Risk Technologies (New York,

10. Nassim Taleb and Gregory Treverton, "The Calm before the Storm," Foreign Affairs, January 2015, at www.foreignaffairs.com/articles/africa/calm-storm (last accessed June 13, 2017).

11. The best treatment remains Stephen Kotkin, Armageddon Averted: The Soviet Collapse 1970-2000, updated ed., (Oxford, UK, 2008). See also Chris Miller, The Struggle to Save the Soviet Economy: Mikhail Gorbachev and the Collapse of the USSR (Chapel Hill, 2016).

12. Angus Maddison, Growth and Interaction in the World Economy: The Roots of Modernity (Washington, 2005); Michael D. Bordo, Barry Eichengreen, and Douglas A. Irwin, "Is Globalization Today Really Different than Globalization a Hundred Years Ago?" (paper presented at the Brookings Trade Policy Forum on "Governing in a global Economy," Washington, April 15-16, 1999). 
inspired by socialism and nationalism. These processes culminated in the outbreak of World War I and the subsequent collapse of the European state system in 1917-18.

Vladimir Lenin witnessed the turmoil of WWI from his political exile in Zurich. Sitting in the Café Odeon (now a gay bar), between January and June 1916, he penned the short book Imperialism: the Highest Stage of Capitalism, a brilliant analysis of the disruptive logic of global capitalism. ${ }^{13}$ When students read Lenin nowadays, the most popular works assigned are What is to Be Done? (1902) and State and Revolution (1917), which address the political innovations for which he is best known-the creation of a vanguard party, and the advocacy of violent use of state power to fulfil his eschatological vision. ${ }^{14}$ However, Imperialism is his intellectual masterpiece, and the only work that really has continuing relevance for our understanding of the present.

Theeconomic analysis in Imperialism was not original-Lenin was drawing on well-known works by John Hobson, Rudolph Hilferding, and his Bolshevik comrade Nikolai Bukharin. ${ }^{15}$ What was distinctive was Lenin's ability to combine that economic analysis with a political analysis of class struggle within the various capitalist countries and their colonies, and on top of that display a grasp of the international military rivalry. Lenin was thus integrating developments across a multiplicity of systems. His "Copernican revolution" was to see that class struggle within the advanced capitalist countries was less important, because of nationalism and the emergence of a "labor aristocracy," than political struggle between countries. This was manifested in the rise of anti-colonial nationalist movements in India, the Dutch East Indies and elsewhere, and in the awkward position of Russia as simultaneously colonizer and colonized. ${ }^{16}$ This meant that Russia represented the "weakest link" in the chain of global imperialism. ${ }^{17}$ Lenin therefore hypothesized that a working class revolution could succeed first in Russia and not in Germany or England, as most orthodox Marxists supposed; and from there it would spread globally until the entire system of world capitalism was destroyed. When revolution broke out on the streets of Petrograd in February 1917, most Marxists assumed that this would lead to a transitional bourgeois government, and that socialist

13. Available online: Vladimir Lenin, "Imperialism, the Highest State of Capitalism" (1917), in Lenin Selected Works, vol. 1 (Moscow, 1963), 667-766, at www.marxists.org/archive/lenin/works/1916/imp-hsc/ (last accessed June 14, 2017).

14. Neil Harding, Lenin's Political Thought (London, 1977).

15. Lenin read over 150 books and made 900 pages of notes in preparing Imperialism. Georges Labica, "From Imperialism to Globalization," in Sebastian Budgen, Stathis Kouvélakis, and Slavoj Žižek (eds.), Lenin Reloaded: Towards a Politics of Truth (Durham, 2007), 222-37, here 223. Lenin wrote the preface for Nikolai Bukharin, Imperialism and the Global Economy (Moscow, 1915), available at: www.marxists.org/archive/bukharin/ works/1917/imperial/intro.htm (last accessed June 14, 2017).

16. The idea that Russia was self-colonizing is of continued relevance to understanding the ambiguities of Russia identity, see: Aleksandr Etkind, Internal Colonization: Russia's Imperial Experience (Cambridge, UK, 2011).

17. The phrase was used by Lenin in a June 9, 1917 article in Pravda entitled "The chain is no stronger than its weakest link." Vladimir Lenin, "The Chain Is No Stronger than its Weakest Link," Pravda, June 9, 1917, in Lenin Collected Works, vol. 24 (Moscow, 1964), 519-20, at www.marxists.org/archive/lenin/works/1917/may/27.htm (last accessed June 14, 2017). 
forces were too weak to try to seize power themselves. On his return to Russia, however, Lenin insisted that global revolution was at hand, and that the workers' movement should seize power. ${ }^{18}$ Stikhiinost', or spontaneity, had long been a central concept in Lenin's revolutionary writings. ${ }^{19}$ He grasped both the contingency of events and the contours of the bigger forces at work. He saw the scope for agency while large power structures were in fateful disarray, and he acted on that knowledge. The Bolsheviks were able to seize and hold power in Russia, but Lenin's assumption that this would necessarily lead to global revolution proved wrong. ${ }^{20}$

Lenin was not alone in foreseeing the impending catastrophe, of course. For example, a memorandum written for the Tsar in February 1914 by former interior minister Petr Durnovo outlined the deadly consequences for Russia of the impending "fight to the death" between England and Germany. He warned that "the financial and economic consequences of defeat can be neither calculated nor foreseen, and will undoubtedly spell the total ruin of our entire national economy," and that "there must inevitably break out in the defeated country a social revolution which, by the very nature of things, will spread to the country of the victor."21

But none of the European leaders who took their country to war in 1914 imagined that it would result in the collapse of the great land empires of Germany, Russia, Austria-Hungary, and Ottoman Turkey. Still less could they have anticipated that a group claiming to represent the world proletariat would seize-and hold-state power in Russia. The German government, of course, sponsored Lenin's return to Russia, so they also exercised agency in this chain of events. ${ }^{22}$ They presumably thought Lenin would cause problems for the Provisional Government, and hopefully take Russia out of the war. But they could not have foreseen that he would actually succeed in taking power and creating a state that, just 28 years later, would crush and occupy Germany itself.

\section{The Phantom of World Revolution}

Lenin's fateful connection of imperialism with capitalism meant that initial Bolshevik policy made revolution in Europe the indispensable condition of their own survival. Though Bolshevik attempts to bring revolution by force or conspiracy were stopped in Poland, Germany, Hungary and elsewhere, the

18. Vladimir Lenin, "The Tasks of the Proletariat in the Present Revolution" [The April Theses], Pravda, April 7, 1917, in Lenin Collected Works vol. 24 (Moscow, 1964) 19-26, at www.marxists.org/archive/lenin/works/1917/apr/04.htm (last accessed June 14, 2017).

19. We are grateful to Alexander Semyonov for this point.

20. Lenin's ideas nevertheless continue to cast a long shadow over leftist intellectuals in the world today. See for example Michael Hardt and Antonio Negri, Empire (Cambridge, MA, 2001); Slavoj Žižek (ed.), Revolution at the Gates: Selected Writings of Lenin from 1917 (London, 2011); and Budgen, Kouvélakis, and Žižek (eds.), Lenin Reloaded.

21. Petr Durnovo, "Memorandum to Nicholas II," February, 1914, at: http://novaonline.nvcc.edu/eli/evans/his242/documents/Durnovo.pdf. He warned against annexing Galicia if Russia won the war, because it would fuel Ukrainian separatism. If only Stalin had heeded that warning in 1945.

22. Catherine Merridale, Lenin on the Train (New York, 2017). 
commitment of Moscow to the propagation of world revolution transformed the nature of international relations, and it undermined early Soviet attempts to gain the measure of economic cooperation that they sought to begin the reconstruction of their economy after seven years of nearly uninterrupted warfare. This ultimately exposed a dilemma that had been hidden in Lenin's conflation of revolution in Russia with the fall of the global imperialist-capitalist system: what to do when the interests of the Soviet Union and that of world revolution were in conflict? Though Communist leaders around the world generally claimed that the interests of the Soviet Union and that of world revolution were necessarily identical, in practice Soviet control over the activities of Communist Parties in other countries through the Comintern and other channels belied this vision of revolutionary unity. ${ }^{23}$ From Jiang Jieshi's massacre of Communists in Shanghai in 1927 to the rise of Hitler and the destruction of the Polish Communist Party by the NKVD in 1937, communists around the world paid the price for believing in a united world revolution. By the time of the Nazi-Soviet Pact of 1939, the golden age of Soviet sympathizers, at least in the west, was at an end.

The Soviet victory in World War II seemed to provide a renewed opportunity to connect the anti-capitalist and anti-imperialist revolutions on a world scale, given the dramatic rise in Soviet power and influence. Despite shortterm successes in eastern Europe and east Asia, however, two long-term factors upset the Soviet vision of a revolutionary march to the west: the failure of the capitalist world to return to a state of economic depression, and the explosion of revolution in the colonial world. This meant that the Soviets were faced with a choice of whether to stick to the original plan and prioritize revolution in the industrialized countries or instead write those countries off for a time and become the patron of the anti-colonial struggle. The latter choice would take Moscow into uncharted territory. The Comintern approach to the colonial and developing world saw it as a means to an end, namely the destabilization of the metropoles with the assumption that independence for the colonies would only come with the fall of capitalism in the west. ${ }^{24}$ Embracing the struggle against colonialism and neocolonialism in the post-WWII era, though, meant finding a way to promote socialism in pre-industrial economies while conducting something like a war of attrition with the west under the cover of "Peaceful Coexistence." 25 In accordance with the imperialismas-final-stage-of-capitalism hypothesis, the Soviets tried to do both, with the consequence that their neglect of the perceived interests of the workers in

23. See, for example, Alexander Pantsov, The Bolsheviks and the Chinese Revolution, 1919-1927, (Honolulu, 2000); Manuel Caballero, Latin America and the Comintern, 19191943, (Cambridge, UK, 2002); Michele Louro, “Rethinking Nehru's Internationalism: The League against Imperialism and Anti-imperial Networks, 1927-1936," Third Frame: Literature, Culture, and Society 2, no. 3, (September 2009) pp. 79-94.

24. See Karl Radek, address to the Baku Congress of the Peoples of the East, September 2, 1920, at www.marxists.org/history/international/comintern/baku/ch02.htm (last accessed June 15, 2017); “Theses on the Eastern Question,” Fourth Congress of the Communist International, December 5, 1922, at www.marxists.org/history/international/ comintern/4th-congress/eastern-question.htm (last accessed June 15, 2017).

25. See Jeremy Friedman, Shadow Cold War: The Sino-Soviet Competition for the Third World (Chapel Hill, 2015), 60-83. 
the west weakened communist parties there while their lukewarm support of revolution in the developing world led many to seek other patrons. ${ }^{26}$

This shift of the revolutionary battleground to the developing world, and the inability of the Soviets to successfully adapt, led to something like a Socialist Reformation. While Moscow's claim to be a sort of Vatican of the international communist movement had never gone completely unchallenged, the 1960s saw a proliferation of alternative potential leaders with their own models, some of whom held the reins of political power, mostly importantly Mao Zedong. With the United States at war in Vietnam, students and others marching in Paris, Berlin, Berkeley, Mexico City and elsewhere, and wars raging from Southern Africa to the Middle East to Southeast Asia, the vision of a global revolution against the imperialist-capitalist system never seemed more compelling. Chasing the elusive dream of restoring a measure of unity in order to re-assert control and affirm its legitimacy, the Soviet leadership tried to embrace these new causes and constituencies, finding itself by the 1980s mired in conflicts in Cambodia, Afghanistan, Ethiopia, Angola, Nicaragua, and beyond. While there were occasional local victories, on a global scale pursuing the anti-imperialist chimera hurt the viability of socialism by draining its resources and reducing its attractiveness to millions of potential adherents, who saw little to admire in the new Soviet client states. ${ }^{27}$

While the Soviet Union proved unable to bring about a comprehensive overthrow of the global system of imperialism and capitalism, Lenin's idea nevertheless grew in popularity as new groups sought to connect their own struggles to global phenomena in innovative ways. From the Trotskyite Fourth International to Maoism, Guevara-ism, the Weathermen, the Red Army Faction and numerous other groups, the idea of a necessary connection between imperialism and capitalism, between ethnic oppression and economic oppression, as the analytical key to the system of global injustice galvanized agendas and imaginations far beyond the bounds of Marxism-Leninism.

\section{7 and the Current Crisis in Global Capitalism}

100 years later we are back in another systemic crisis whose contours are only dimly understood, and which has already produced a series of black swans which went against all the models of economic and political behavior, based on extrapolation of past experience. In the 2000s, all countries experienced financial crises of greater frequency and depth-and recovery times from the

26. For example, on the Soviet failure to support the FLN (National Liberation Front) in Algeria out of consideration for the French Communist Party, see: Jeffrey Byrne, Mecca of Revolution: Algeria, Decolonization, and the Third World Order (Oxford, UK, 2016), 59. On the tensions that the Soviet policy of peaceful coexistence produced with North Vietnam, see: Pierre Asselin, Hanoi's Road to the Vietnam War: 1954-1965 (Berkeley, 2013), 34-36.

27. For the impact on Soviet resources, see Stephen Kotkin and Jan T. Gross, Uncivil Society: 1989 and the Implosion of the Communist Establishment (New York, 2009), 50; Margot Light, "Introduction: The Evolution of Soviet Policy in the Third World," in Margot Light, ed., Troubled Friendships: Moscow’s Third World Ventures (London, 1993), 21. 
2008 crash have been particularly protracted. ${ }^{28}$ This has produced numerous reincarnations of the imperialism-capitalism hypothesis which, despite being politically at odds, bear a rhetorical and at times tactical similarity that reveals their common origins, almost like lexical and syntactical evidence of a common linguistic origin. These sorts of connections can be drawn between the anti-globalization movement that burst onto the scene with the WTO protests in Seattle in 2000, China's appeal to African leaders on the basis of anti-imperialism through the Forum on China-Africa Cooperation, and even movements committed to global jihad. The alliance of Hugo Chavez and Mahmoud Ahmedinejad in the 2000s would be nearly inexplicable without Lenin's 1916 pamphlet.

For Russia, Lenin's key insight was that its problems must be understood in a global context, as the result of complex forces operating far beyond Russia's borders. The same admonition applies globally to the current crisis-people are searching for solutions at the national level (trade barriers if you are a protectionist, investment in $R \& D$ and human capital if you are a liberal), but the stagnant wages and rising inequality of the advanced economies are the product of tectonic shifts in global economic power towards China and other emerging economies that are rapidly building the institutions and infrastructure to connect them to the global division of labor. This means that, once again, the solutions to rapidly rising inequality due to the uneven distribution of the benefits of globalization cannot be found inside national borders, any more than "socialism in one country" could produce lasting prosperity for Soviet citizens. Though the politics of national preservation seem ascendant in the west at the moment, geopolitical rivalry will make it impossible to completely stop globalization, as China's assumption of the Trans-Pacific Partnership mantle in the wake of the US election indicates. A century after Lenin wrote, with the movement of capital, information and technology increasing ever more rapidly, no country can hope to achieve sustained prosperity and stability by isolating itself from the global economy.

Nowhere are these contradictions more visible than in Russia itself. Russia's economy is heavily dependent on the sale of oil and gas to Europe. But Russia has been excluded from European institutions such as NATO and the European Union, and Moscow has turned to denouncing European values in increasingly strident terms since 2011. In the wake of the annexation of Crimea in 2014, Russian nationalists urged Putin to cut Russia's economic dependence on the west, but he has not yet fully embraced their agenda. Global integration serves Russia's crony capitalists all too well. ${ }^{29}$

Russians are also in a conundrum when it comes to marking the centenary of the 1917 revolutions. ${ }^{30}$ Lenin is no longer venerated as the founder of

28. Michael Jacobs and Marianna Mazzucato, Rethinking Capitalism: Economics and Policy for Sustainable and Inclusive Growth (Chichester, 2016).

29. Peter Rutland, "The Place of Economics in Russian National Identity Debates," in Pål Kolstø and Helge Blakkisrud eds., The New Russian Nationalism: Imperialism, Ethnicity, and Authoritarianism 2000-2015 (Edinburgh, 2016), 336-61.

30. Fedor Krashchennikov, "Politicheskii Dnevnik: Neudobnyi 17-i god" (Political Journal: The Inconvenient Year of 1917) Vedomosti, November 2, 2016; Mark Edele, "Friday Essay: Putin, Memory Wars and the $100^{\text {th }}$ Anniversary of the Russian Revolution," 
the Soviet state. Russians themselves are acutely aware that it was global integration that led to the destruction of their state twice in the past century-in 1917 and $1991 .{ }^{31}$ For Russia, therefore, the conception of a hostile imperialist world order directed against them remains. Socialism proved unable to defeat it, and the search for an alternative approach has been bloody and fruitless. Putin's attempt to return to Russia's imperial past, though popular, seems like another dead end. Despite its best efforts to create a sort of far-right "international" in Europe as a way of positioning itself as the alternative to the west, Russia, bereft of its empire and lacking its former political and ideological attractiveness, will be hard-pressed to create an international coalition to battle its perceived imperialist enemies. Perhaps, contra Lenin, Russia would be best-served by finally getting its own house in order.

The Conversation, February 9, 2017 at http://theconversation.com/friday-essay-putinmemory-wars-and-the-100th-anniversary-of-the-russian-revolution-72477 (last accessed June 15, 2017).

31. Roman Gazenko and Aleksei Martinov, Ideal'nyishtorm": Tekhnologiia razrusheniia gosudartsva (Perfect Storm: The Technology of State Destruction) (Moscow, 2016). 